\title{
Fanatisme Jamaah Pengajian Agama terhadap Guru Zuhdi di Masjid Jami Banjarmasin
}

\author{
Novisari, Yulia Hairina, dan Siti Faridah \\ Universitas Islam Negeri Antasari Banjarmasin
}

\begin{abstract}
Fanaticism is an over-zealous attitude towards a particular perspective or attitude regarding community practice. For the recitation pilgrims, the Zuhdi teacher himself has a figure that is one of the things that is positive for everyone, because the respected figure is considered to be able to provide benefits that are considered positive and deserve fanaticism from many communities. How a person interacts is inseparable from the environment that shapes a person's personality. This type of research is a descriptive-qualitative field research, the method used by the author is a method for examining an object from a state of condition or a system of thought from the subject, the researcher collects a number of data obtained directly from the research location using information obtained from the object research through data collection instruments namely observation and interviews. Because Zuhdi teacher recitation worshipers at the Mosque of Jami are very many and from various backgrounds. Data collection techniques used are fanaticism scale, semi-structured interviews, and non-participant observation with subjects totaling 4 people with characteristics of recitation congregation aged 20-50 years. Based on the results that researcher have obtained in all four subjects have a dimension of fanaticism, the amount of interest and love for one type of activity, $S$ and MI subjects have a strong interest, while the MA and $Z$ subjects have a very strong interest because it attaches photos of Master Zuhdi at home and even saves photos and his deeds in special notes. So, fanaticism is a concept adopted by someone who has contributed to his life and makes his emotions become more mature or wise. Fanaticism in this study is one form of love and belonging to a society/group of figures who are believed to have made a major contribution in themselves and their lives.
\end{abstract}

Keywords: fanaticism; recitation congregation; Zuhdi teacher; Banjarmasin.

Abstrak
Fanatisme adalah satu sikap penuh semangat yang berlebihan terhadap satu segi pandangan
atau satu sikap tertentu mengenai praktik masyarakat. Bagi jamaah pengajian Guru Zuhdi
sendiri mempunyai seorang figur itu merupakan salah satu hal yang positif bagi setiap orang,
karena tokoh yang disanjung dinilai dapat memberikan manfaat yang dianggap positif dan
layak mendapatkan fanatisme dari banyak masyarakat. Hal itu yang terlihat dari gambaran
masyarakat muslim di Kota Banjarmasin yang memiliki ikatan kuat, pantang tidak hadir
ketika pelaksanaan pengajian atau ceramah Guru Zuhdi. Berdasarkan dari paparan latar
belakang, maka dalam hal ini peneliti tertarik meneliti fanatisme jamaah pengajian agama
terhadap Guru Zuhdi di Mesjid Jami Banjarmasin serta mengidentifikasi faktor yang
mempengaruhi fanatismenya. Jenis penelitian ini adalah penelitian lapangan yang bersifat
deskriptif-kualitatif, metode yang digunakan penulisialah metode untuk meneliti suatu objek
dari suatu keadaan kondisi maupun suatu sistem pemikiran dari subjek, peneliti
mengumpulkan sejumlah data yang diperoleh langsung dari lokasi penelitian dengan
menggunakan informasi yang didapat dari obyek penelitian melalui instrumen
pengumpulan data yakni observasi dan wawancara. Karena jamaah pengajian Guru Zuhdi di


Mesjid Jami sangat banyak dan dari berbagai kalangan. Teknik pengumpulan data yang digunakan adalah skala fanatisme, wawancara semi terstruktur, dan observasi non partisipan dengan subjek yang berjumlah 4 orang dengan karakteristik jamaah pengajian yang berusia yaitu 20-50 tahun. Berdasarkan hasil yang telah peneliti dapatkan pada keempat subjek yang memiliki dimensi fanatisme, besarnya minat dan kecintaan pada satu jenis kegiatan, subjek $S$ dan MI memiliki minat yang kuat, sedangkan subjek MA dan Z memiliki minat yang sangat kuat karena menempel foto Guru Zuhdi di rumah bahkan menyimpan foto serta amalan beliau di catatan khusus. Jadi, fanatisme adalah suatu paham yang dianut oleh seseorang yang telah memberi andil terhadap kehidupannya dan membuat emosinya menjadi lebih matang atau bijaksana. Fanatisme dalam penelitian ini adalah salah satu wujud dari rasa cinta yang dimiliki suatu masyarakat/golongan pada sosok figur yang diyakini telah memberikan kontribusi yang besar dalam dirinya dan hidupnya.

Kata kunci: fanatisme; jamaah pengajian; Guru Zuhdi; Banjarmasin.

Bangsa Indonesia dikenal sebagai bangsa religius, yang kehidupan masyarakatnya kental dengan aktivitas dan semangat keagamaan (Faridah \& Mubarak, 2017). Hal ini pun terlihat pada masyarakat Banjar di Kalimantan Selatan yang nuansa religiusnya tergambar oleh lantunan kumandang azan yang saling bersahutan dari masjid atau surau-surau yang jaraknya sangat berdekatan satu sama lain. Selain itu, kota ini juga terdapat begitu banyak destinasi wisata religi yang selalu tak luput dari kunjungan para wisatawan, sebut saja seperti makam-makam para ulama, kiai, atau habib yang sampai sekarang masih menjadi daya tarik tersendiri untuk kota yang memiliki semboyan seribu sungai ini.

Kalimantan Selatan merupakan provinsi yang dihuni oleh mayoritas suku Banjar. Sebelum Islam masuk ke daerah Banjar, di sana sudah ada kerajaan Hindu sebagai pengaruh Sriwijaya dan Majapahit. Islam masuk ke daerah Banjar pada abad ke-16, tepatnya pada tahun 1526 M. Adapun proses islamisasi daerah Banjar dilakukan oleh kerajaan Demak, sebuah kerajaan Islam di daerah pantai utara pulau Jawa kala itu (Ilhami, 2010). Islam yang berkembang di daerah Banjar adalah Islam kultural (Islam yang berkembang secara alamiah membudaya di masyarakat) yaitu Islam berwujud atau melahirkan sesuatu yang tidak ada dilakukan Rasulullah Saw. dan para sahabat, tetapi ia dapat dipandang sebagai pengejawantahan dari ajaran Islam tersebut. Dari konsep itu dilahirkan sebuah bentuk kegiatan yang dinyatakan sebagai budaya Islam, seperti peringatan Isra Mikraj Nabi Saw., Maulid Nabi Saw., acara "Nuzulul Quran", dan lain-lain. Semuanya ini dilakukan dalam 
rangkaian pembinaan ukhuwah islamiah dan aktivitas dakwah seperti yang diajarkan dalam al-Quran dan hadis (Lubis, 2014).

Islam yang berkembang di daerah Banjar tidak jauh berbeda dengan Islam di Jawa. Dinamika perkembangan Islam di Banjar mengalami perkembangan yang cukup signifikan, dari Islam kultural menjadi sedikit formal, ketika Syekh Muhammad Arsyad Al-Banjari kembali dari Mekkah pada tahun $1772 \mathrm{M}$, beliau melakukan intensifikasi pengetahuan keagamaan masyarakat Banjar dan melibatkan Islam dalam birokrasi kesultanan Banjar. Proses ini menemukan bentuk formalnya pada tahun $1835 \mathrm{M}$ ketika dikukuhkannya UndangUndang Sultan Adam sebagai dasar orientasi sosial keagamaan masyarakat Banjar (Ilhami, 2010). Oleh sebab itulah orang Banjar dikenal sebagai mayoritas pemeluk agama Islam. Berdasarkan sensus yang ada, jumlah pemeluk agama Islam di Kalimantan Selatan mencapai lebih dari 97\%. Jumlah yang besar ini tentu bukan sesuatu yang terwujud secara tiba-tiba. Ia adalah hasil dari usaha-usaha dakwah yang dilakukan, terutama oleh tokoh-tokoh agama Islam yang disebut dengan ulama. Karena itu pula, para ulama memiliki kedudukan penting dalam kehidupan masyarakat Banjar hingga sekarang (Mujiburrahman dkk., 2012).

Berbagai sebutan untuk ulama seperti guru, mualim dan ustaz secara jelas dan langsung menunjukkan bahwa seorang ulama adalah pendidik. Karena itu, membicarakan ulama tidak bisa terlepas dari pendidikan, baik pendidikan yang pernah ia jalani, ataupun pendidikan yang ia rintis untuk masyarakatnya. Perkembangan sosial, budaya, dan politik yang terjadi dari masa ke masa, tentu turut mempengaruhi jenis pendidikan apa yang ditempuh oleh seorang ulama di satu sisi dan model pendidikan seperti apa yang mereka kembangkan untuk masyarakat di sisi lain. Kedua sisi ini saling berhubungan dalam membentuk dan menjaga otoritas keagamaan ulama di masyarakat. Model pembelajaran yang dilaksanakan masyarakat Banjar dulu ialah pengajian yang mengikuti sistem halakah, sistem halakah ialah di mana murid-murid duduk berkeliling di hadapan guru, dalam budaya Banjar dikenal dengan sebutan mengaji baduduk (Mujiburrahman dkk., 2012).

Demikianlah gambaran dinamika ulama di Kalimantan Selatan, yang terus mengalami perkembangan hingga saat ini. Keberadaannya dari masa ke masa terus memainkan sentral kehidupan umat Islam di kawasan ini. Hal ini tidak lain, karena selain peran ulama sebagai pendidik, pemimpin ibadah, dan pejuang politik, perannya yang lebih penting adalah sebagai konsultan bagi masyarakat dalam menghadapi persoalan hidup. Seorang ulama di 
masyarakat Banjar biasanya melayani masyarakat nyaris tiap hari, siang dan malam. Peran ulama sebagai pengayom dan pelipur hati masyarakat itu dapat pula terjadi secara tidak langsung, yakni di pengajian-pengajian yang ia berikan.

Banyak pengajian yang dilaksanakan di Kalimantan Selatan, khususnya di ibukota provinsi Kalimantan Selatan sendiri yaitu Banjarmasin. Menurut data terkini dari Kementerian Agama Kota Banjarmasin tahun 2014 ada sekitar 272 majelis taklim yang ada di kota Banjarmasin yang tersebar di lima kecamatan. Dari data majelis taklim dapat diketahui bahwa kecamatan Banjarmasin Barat memiliki majelis taklim terbanyak (70 majelis), disusul kecamatan Banjarmasin Selatan (53 majelis), kemudian Banjarmasin Timur (51 majelis), Banjarmasin Tengah (49 majelis), dan Banjarmasin Utara (49 majelis). Sedangkan jumlah tokoh agama yang tercatat di kantor Kementerian Agama Kota Banjarmasin tahun 2014 berjumlah 311 orang. Tokoh agama yang masuk dalam kategori ulama menurut perhitungan Kementerian Agama Kota Banjarmasin sebanyak 161 orang. Tokoh agama yang masuk kategori khatib sebanyak 256 orang. Tokoh agama yang masuk sebagai kategori dai atau mubalig sebanyak 232 orang dan yang masuk dalam kategori daiyah atau mubaligah yang tercatat di Kementerian Agama Kota Banjarmasin tahun 2014 sebanyak 37 orang (Banjarmasin, 2014).

Di antara tokoh-tokoh agama yang tersebut di atas ada satu ulama Banjarmasin yang terkenal dengan jamaahnya yang mencapai puluhan ribu orang, beliau dikenal dengan nama Guru Zuhdi. Ulama karismatik yang bertempat tinggal di Jalan Masjid Jami (belakang Masjid Jami) tidak hanya terkenal dengan jamaahnya yang berjumlah puluhan ribu, tetapi juga sikap rendah hatinya. Tidak ada rasa tinggi hati dari beliau, walaupun beliau adalah salah satu ulama yang paling banyak jamaahnya saat ini di Banjarmasin. Selanjutnya dalam wawancara penulis dengan salah satu murid beliau mengatakan kalau saat hari raya kurban Guru Zuhdi menyumbangkan sapi untuk dijadikan sebagai hewan kurban, dan tak segan-segan beliau ikut langsung dalam proses pemotongan hewan kurban, tak ada rasa malu saat tangan hingga baju beliau kotor oleh darah hewan kurban, beliau tetap rendah hati dengan senyum tulus yang terlukis di wajah beliau. Tidak hanya itu beliau juga kadang-kadang ikut serta dalam aksi pemadam kebakaran (MA, 2016).

Keseharian beliau yang bersahaja, rendah hati, serta murah senyum tergambar pula saat beliau mengisi ceramah, beliau juga selalu mengingatkan agar menjalani hidup lebih 
santai dan tenang serta menghadapi semua dengan senyuman. Pembawaan beliau yang santai serta murah senyum, Guru Zuhdi mendapatkan banyak tempat di hati para jamaahnya, ceramah beliau yang jelas dalam pengucapan setiap kalimat disertai ekspresi wajah serta gerakan tubuh yang menggambarkan apa yang sedang beliau terangkan membuat para jamaah tidak merasa bosan atau mengantuk di saat mendengarkan ceramah beliau. Hasil wawancara penulis dengan beberapa orang jamaah Guru Zuhdi pada pengajian pagi Minggu di Masjid Sabilal Muhtadin menghasilkan keterangan bahwa Guru Zuhdi sangat jelas dalam menerangkan ilmu-ilmu agama hingga hal kecil seperti batasan-batasan haid seorang wanita pun diterangkan dengan jelas. Salah satu jamah juga menerangkan kalau cara ceramah beliau yang kadang duduk kadang berdiri untuk memberikan contoh guna memperjelas atas apa yang telah beliau sampaikan, raut wajah beliau hingga gerakan tangan beliau yang menegaskan atas apa yang sedang beliau sampaikan membuat jamaah beliau makin paham dengan ilmu agama yang sedang beliau sampaikan (MA, 2016). Karena karismatik yang ada pada Guru Zuhdi itulah yang membuat masyarakat menjadi jamaah yang sangat mengidolakan dan fanatik terhadap pengajian beliau.

Dalam dunia psikologi, fanatisme adalah satu sikap yang penuh semangat yang berlebihan terhadap satu segi pandangan atau satu sebab tertentu mengenai praktik masyarakat (Chaplin, 2008). Sikap fanatisme muncul dikarenakan adanya rasa cinta mengenai golongan atau daerah atau cinta terhadap figur yang menjadi tokoh karismatik di masyarakat. Bagi jamaah pengajian Guru Zuhdi sendiri, mempunyai seorang figur itu merupakan salah satu hal yang positif bagi setiap orang, karena tokoh yang disanjung dinilai dapat memberikan manfaat yang dianggap positif dan layak mendapatkan fanatisme dari banyak masyarakat.

Bagaimana cara seseorang berinteraksi, tidak terlepas dari lingkungan sekitar yang membentuk kepribadian seseorang. Begitu pula seorang penceramah, apa yang disampaikan dan bagaimana cara menyampaikan, semua terbentuk akibat dengan siapa dirinya (penceramah) berkomunikasi. Semua itu menjadi faktor pendukung seorang penceramah banyak memiliki pengikut yakni jamaahnya yang sangat mencintai dan fanatik terhadap keberadaan beliau. Hal itu yang terlihat dari gambaran masyarakat muslim khususnya yang ada di Kota Banjarmasin yang memiliki ikatan kuat, pantang tidak hadir ketika pelaksanaan 
pengajian atau ceramah beliau. Ikatan itulah yang menjadi sebuah fanatisme yang ada pada diri masyarakat terhadap sosok Guru Zuhdi tersebut.

\section{Metode}

Penelitian ini merupakan jenis penelitian lapangan (field research) yang bersifat deskriptif-kualitatif. Metode deskriptif yang digunakan penulis ialah metode untuk meneliti suatu objek dari suatu keadaan kondisi maupun suatu sistem pemikiran dari subjek (Prastowo, 2011). Penelitian lapangan sejenis ini memerlukan pengumpulan sejumlah data yang diperoleh langsung dari lokasi penelitian, dengan menggunakan informasi yang didapat dari obyek penelitian atau yang disebut dengan informan melalui instrumen pengumpulan data yakni observasi dan wawancara. Penelitian jenis kualitatif ini biasanya merujuk pada data primer yang diperoleh dari individu, kelompok orang, keluarga, komunitas, bahkan organisasi. Penelitian lapangan yang bersifat deskriptif-kualitatif juga sangat relevan untuk menemukan realitas dengan menggali pengalaman seseorang terhadap sesuatu baik tentang suatu kejadian, proses, interaksi, dan struktur kehidupan yang terjadi pada suatu subjek (Wibowo, 2014).

Pendekatan yang digunakan dalam penelitian ini adalah pendekatan kualitatif, yakni prosedur penelitian yang menghasilkan penelitian data berupa kata-kata tertulis atau lisan tentang orang-orang, perilaku yang dapat diamati sehingga menemukan kebenaran yang dapat diterima oleh akal sehat manusia (Metodologi Penelitian Pendidikan, 2007). Menurut Bogdan dan Taylor, penelitian kualitatif adalah "prosedur penelitian yang menghasilkan data deskriptif berupa kata-kata tertulis atau lisan dari orang-orang dan perilaku yang diamati" (Moleong, 2009). Metode ini sering juga dinamakan dengan metode naturalistik karena penelitiannya dilakukan pada kondisi yang alamiah (natural setting); disebut juga sebagai metode etnografi (ilmu mengenai gambaran) (Sugiyono, 2013).

Penelitian ini bermaksud melakukan observasi dengan melakukan pengamatan naturalistik kepada jamaah Guru Zuhdi di majelis pengajian beliau yakni di Masjid Jami Banjarmasin. Setelah melakukan pengamatan beberapa waktu penulis akan melakukan wawancara kepada masyarakat yang menjadi jamaah untuk mencari hasil penelitian fanatisme jamaah pengajian agama terhadap Guru Zuhdi sebagai subjek penelitian. 
Kemudian peneliti dapat menghasilkan data deskriptif berupa gambaran fanatisme jamaah pengajian agama terhadap Guru Zuhdi di Masjid Jami Banjarmasin.

\section{H a s i 1}

Subjek pada penelitian ini berjumlah empat orang masyarakat Banjarmasin yang sering ke pengajian Guru Zuhdi di Masjid Jami Banjarmasin dengan usia yang beragam mewakili setiap generasi, adapun tabel identitas subjek penelitian ialah sebagai berikut:

\section{Tabel 1}

Identitas Subjek Penelitian

\begin{tabular}{ccccc}
\hline Subjek (Inisial) & Usia & Alamat Tempat Tinggal & Status & Agama \\
\hline S & 52 & Jl. A. Yani Komplek Palapan & PNS & Islam \\
MA & 30 & Jl. Brigjend Hasan Basri Komplek & Guru & Islam \\
MI & 26 & Kayutangi 1 & Honorer & \\
& Jl. Kapoer Naga Komplek Banjar & Indah Permai & Dosen & Islam \\
Z & 48 & Jl. Mangga Besar, Komplek & Pedagang & Islam \\
\hline
\end{tabular}

Peneliti membuat tabel ringkasan hasil penelitian yang telah peneliti dapatkan berdasarkan hasil observasi dan wawancara keempat subjek. Yaitu sebagai berikut;

Tabel 2

Ringkasan Pola Asuh Subjek

\begin{tabular}{ccccc}
\hline Dimensi Fanatisme & S & MA & MI & Z \\
\hline $\begin{array}{c}\text { Besarnya minat dan kecintaan pada satu } \\
\text { jenis kegiatan. }\end{array}$ & Kuat & Sangat Kuat & Kuat & Sangat Kuat \\
$\begin{array}{c}\text { Sikap pribadi maupun kelompok } \\
\text { terhadap kegiatan tersebut. }\end{array}$ & Sangat Kuat & Kuat & Kuat & Sangat Kuat \\
$\begin{array}{c}\text { Lamanya individu menekuni satu jenis } \\
\text { kegiatan tertentu. }\end{array}$ & Sangat Kuat & Sangat Kuat & Kuat & Sangat Kuat \\
$\begin{array}{c}\text { Motivasi yang datang dari keluarga juga } \\
\text { mempengaruhi seseorang terhadap } \\
\text { bidang kegiatannya. }\end{array}$ & Sangat Kuat & Sangat Kuat & Kuat & Sangat Kuat \\
\hline & & & & \\
\hline
\end{tabular}

Menurut Goddard (2001) aspek-aspek yang mempengaruhi fanatisme yaitu: Besarnya minat dan kecintaan pada satu jenis kegiatan. Pada aspek ini ditunjukkan oleh hampir semua subjek, sesibuk apa pun mereka menyempatkan datang ke pengajian, hal tersebut di ungkapkan oleh beberapa subjek:

Hampir kada pernah kada hadir pengajian beliau yang di Masjid Jami. (Subjek S) 
Inggih harus mba, kalau kada datang rasa ada yang kosong mbak ae. Biasanya ulun sudah mengatur jadwal terlebih dahulu supaya ulun tetap bisa pergi ke pengajian beliau, kecuali ada hal yang di luar kuasa ulun yang sangat penting sehingga ulun kada kawa berhadir, selebihnya ke pengajian lebih diutamakan" (Subjek S)

Alhamdulillah rutin datang ke pengajian beliau, kecuali memang sangat ada kesibukan yang tidak bisa di tinggalkan baru tidak hadir, tapi saya usahakan untuk tetap hadir ke pengajian beliau. (Subjek MI)

Hal serupa juga di ungkapkan oleh subjek Z ketika di tanya tentang menaruh foto Guru Zuhdi:

Di rumah ada, di hp saya juga ada, di sosial media saya juga ada, sesekali saya upload video ceramah beliau, ya sambil-sambil kita berbagi ilmu karena saya juga sambil belajar. (Subjek Z)

Tentang menaruh foto Guru Zuhdi di rumah juga di akui oleh subjek MI, dan ini alasan subjek ketika ditanya apa alasannya:

Saya kagum sama beliau dan beliau tuh panutan saya, supaya ingat terus sama sidin jadi saya taruh foto beliau di rumah. (Subjek MI)

Menurut Goddard Besarnya Minat dan kecintaan pada suatu kegiatan memiliki makna sebagai intensitas atau tingkatan kecenderungan individu berkaitan dalam menunjukkan usahanya pada suatu kegiatan ataupun hal-hal yang dicintainya. Seorang individu yang memiliki kecintaan yang terlalu besar pada suatu hal, maka individu tersebut akan mendedikasikan atau mengabdikan dirinya pada hal tersebut. Hal tersebut akan membuat individu memunculkan usaha-usaha untuk memajukan atau mempertahankan eksistensi sesuatu yang dicintainya.

Adapun aspek lain dari Goddard yaitu tentang sikap pribadi maupun kelompok terhadap kegiatan tersebut, pada aspek ini subjek mengungkapkan bahwa merasa nyaman ketika berada di pengajian Guru Zuhdi, hal ini di ungkapkan beberapa subjek dalam wawancara:

Tenang, nyaman, sejenak ulun bisa merasakan ulun terbebas dari semua urusan duniawi. (Subjek S)

Ya sangat nyaman, apalagi dimanage oleh para anggota majelis talim yang siap siaga membantu tata letak parkir, mengarahkan para jamaah di mana pintu masuk laki-laki dan perempuan di pisah, pokoknya bagus sekali membuat sangat nyaman dalam mendengarkan ceramah Guru Zuhdi. Merasa sangat tenang, nyaman, seakan semua beban terasa hilang, pokoknya sangat nyaman berada dan mendengarkan ceramah di majelis beliau. (Subjek MA) 
Sikap pribadi maupun kelompok merupakan landasan individu untuk memulai atau memotivasi diri dalam melakukan suatu kegiatan yang dicintainya. Sikap menurut Notoatmodjo merupakan reaksi atau respons yang masih tertutup dari seseorang terhadap suatu stimulus, disertai adanya perasaan tertentu, dan memberikan dasar pada orang tersebut untuk membuat respons atau berperilaku dalam cara tertentu yang dipilihnya. Hal ini berarti bahwa setiap individu memunculkan respons-respons berupa perilaku yang digunakan sebagai dasar dalam melakukan atau menjalankan kegiatan yang dicintai atau diminatinya.

Adapun aspek lain dari Goddard tentang Fanatisme ialah lamanya individu menekuni satu jenis kegiatan tertentu, rata-rata subjek sudah mengikuti pengajian sudah dalam jangka waktu yang lama, bahkan subjek S mengakui sudah mengikuti pengajian selama 10 Tahun.

Sudah sangat lama sekali, 10 tahunan lebih, lupa ulun (Subjek S)

Saya ikut pengajian beliau tuh sejak kalau tidak salah saya ingat sekitar 8 atau 9 tahun yang lalu (Subjek MI)

Menurut Goddard Lamanya individu menekuni satu jenis kegiatan. Merupakan seberapa sering intensitas individu memberikan waktunya untuk melakukan kegiatan yang ada pada suatu hal yang dicintainya. Namun, dalam melakukan sesuatu haruslah ada perasaan yang senang dan bangga terhadap apa yang dikerjakan dan sesuatu hal tersebut lebih bermakna jika mempunyai rasa kecintaan terhadap apa yang dilakukan.

Adapun aspek lain dari Goddard yaitu tentang motivasi yang datang dari keluarga juga mempengaruhi seseorang terhadap bidang kegiatannya. Beberapa subjek mengatakan mereka di dukung keluarga ketika ikut pengajian Guru Zuhdi, berikut pernyataan beberapa subjek seperti:

Ulun selalu pergi dengan istri ulun, karena anak-anak ulun semua di pesantren, kalau mereka libur sekolah pulang ke rumah, ulun juga bawa anak-anak." Subjek S “iya mbak, keluarga ulun bahkan keluarga besar ulun ikut pengajian beliau bahkan sudah sejak lama, mungkin semenjak pertama pengajian beliau dibuka, mereka juga tipe-tipe orang yang selalu sebisa mungkin harus hadir ke pengajian beliau. (Subjek MA)

Motivasi yang datang dari keluarga menurut Goddard adalah motivasi yang didapat oleh individu dapat berasal dari dalam diri sendiri maupun dari luar individu. Motivasi yang didapat dari luar di antaranya datang dari keluarga atau orang-orang terdekat. Keluarga atau 
orang terdekat mampu mempengaruhi individu karena memiliki kedekatan emosional yang kuat sehingga mampu untuk mempengaruhi individu tersebut.

\section{Pembahasan}

\section{Sosok Karismatik Guru Zuhdi}

Pengajian-pengajian tasawuf banyak terdapat di Banjarmasin, namun dalam sebagian besar pengajian tasawuf lainnya hanya membacakan kitab dan lebih cenderung kepada penjelasan tentang pendekatan diri kepada Allah SWT, oleh karena itulah Guru Zuhdi merupakan sosok seorang tokoh agama yang mempunyai kharisma yang sangat luar biasa bagi masyarakat, dengan penyampaian dan pendekatan yang beliau lakukan dalam hal agama pada masyarakat membuat Guru Zuhdi banyak disenangi oleh masyarakat dari berbagai kalangan. Selain itu pengajian tasawuf Guru Zuhdi memakai kitab Al-Nashaih Addiniyyah yang menurut Guru Zuhdi sendiri kitab ini dapat menjadikan masyarakat bisa dekat dengan Allah SWT dan menghargai hukum-hukum dalam agama, selain itu juga kitab tersebut dikarang oleh zuriahnya rasul dan diceritakan bahwa barang siapa yang membaca kitab tersebut akan mendapatkan hadrah (rahmat) oleh Allah Ta'ala, serta pelajaran yang ada dalam kitab itu adalah amalan-amalan yang dilakukan manusia supaya menjadi lebih baik dan terarah dalam perilaku kehidupan sehari-hari (Muhidin, 2015).

Perilaku Fanatisme jamaah pengajian Guru Zuhdi ini tidak terlepas dari karismatik beliau yang sangat di kagumi warga Banjarmasin, hal ini juga di kemukakan di dalam jurnal Al-Banjari yang menjelaskan tentang sosok karismatik Guru Zuhdi. Pengaruh Guru Sekumpul terhadap Guru Zuhdi sangat kuat. Pada banyak hal beliau selalu merujuk kepada figur sang guru ini, seperti dalam hal tarekat, beliau mengikuti Tarekat Sammaniyah. Bahkan dalam berpakaian pun ketika mengisi pengajian, beliau sangat mirip dengan ulama karismatik asal Martapura ini, yakni baju putih dengan serban besar di kepala. Kitab-kitab yang beliau pelajari selama menjadi santri yaitu: pada bidang tauhid, Syarah Hud Hudi karya Imam Syarkawi, Syarah Dasuqi karya Imam Sanusi, Matan Sanusiah karya Imam Sanusi, dan Kifayatul Awal karya Syekh Fudhali. Pada bidang tasawuf, Bidayatul Hidayah karya Imam Ghazali, Minhajul Abidin karya Imam Ghazali, Ihya Ulumuddin karya Imam Ghazali, dan Taqribul Ushul karya Syekh Zaini Dahlan. Pada bidang fikih, Syarah Sitin karya Syekh Ramli, Syarah Bajuri karya Syekh Bajuri, dan Syarah I'anatuthalibin karya Syekh Zainuddin. 
Sedangkan pada ilmu nahwu, Matan Jurumiah karya Imam Sanhaji, Mukhtasar Jidan karya Syekh Zaini Dahlan, Syarah Syekh Khalid karya Syekh Khalid, dan Alfiah Ibnu Malik karya Ibnu Malik (Mujiburrahman dkk., 2012).

Guru Zuhdi, sebagai tokoh yang paling muda dan muncul di masyarakat urban Banjarmasin, ia tidak/belum dibanggakan murid-muridnya sebagai orang yang memiliki karamah. Tetapi justru di situlah letak kekuatannya. Ia bisa tampil di masyarakat perkotaan sebagai figur yang dikagumi dan menyentuh hati. Guru Zuhdi, yang sering mengajarkan tauhid dan tasawuf, dan menekankan betapa pentingnya membersihkan hati, tampil sebagai tokoh rendah hati yang tulus. Ia juga konsisten di jalur agama, tidak mau ikut dalam permainan politik, seperti mendukung politisi tertentu dalam pemilu. Namun ada hal lain yang bagaimanapun menunjukkan bahwa Guru Zuhdi menjadi karismatik antara lain karena faktor gen. Ia memang bukan keturunan al-Banjari, tetapi ia sendiri adalah anak seorang ulama yang dihormati, Tuan Guru Haji Muhammad, yang pernah menjadi pimpinan puncak Pondok Pesantren Al-Falah, Banjarbaru, sebuah pesantren yang memiliki ribuan alumni dan santri. Paman Guru Zuhdi adalah Tuan Guru H. Muhammad Sani, yang dikenal dengan sebutan 'Guru Tani', adalah ulama terkemuka di Banjarmasin, dan pendiri Pondok Pesantren Al-Falah (Mujiburrahman dkk., 2012).

Jika merujuk kepada teori Weber, maka kita akan menemukan kesulitan perihal karisma yang diwariskan ini. Weber memang mengakui bahwa karisma itu ada yang bersifat kekeluargaan, tetapi menurutnya, karisma yang diwariskan akan mudah redup. Kita tak bisa menolak bahwa faktor keturunan bisa menjadi dasar bagi terciptanya karisma. Tentu saja, jika hanya faktor keturunan satu-satunya yang ditonjolkan, karisma mungkin tidak akan bertahan. Faktor-faktor lain, terutama kemampuan sang tokoh merespons kebutuhankebutuhan masyarakatnya, mungkin lebih menentukan ketimbang faktor keturunan. Hal ini mungkin pula dapat menjelaskan, mengapa Guru Zuhdi yang secara garis keluarga tidak berhubungan langsung dengan al-Banjari, tetapi sedikit banyak dapat mewarisi karisma Guru Sakumpul. Ia dianggap demikian karena penampilan dan sikapnya amat mirip dengan sang Guru. Maka kerinduan masyarakat pada Guru Sakumpul, seolah terobati dengan penampilan Guru Zuhdi (Mujiburrahman dkk., 2012).

Selain itu, Weber juga menegaskan bahwa karisma lahir karena keistimewaan sang tokoh yang dapat mewujudkan keajaiban-keajaiban. Tetapi karena keajaiban itu tidak selalu 
terjadi, maka karisma akan memasuki rutinitas dan pelembagaan. Hal serupa tampaknya memang terjadi pada ketiga tokoh kita ini. Rutinitas itu tampak jelas pada pengajianpengajian yang mereka isi secara rutin, dengan jemaah yang lebih kurang rutin juga. Ada ritus-ritus yang rutin dikerjakan, seperti salat hajat berjamaah, membaca maulid al-Habsyi dan ceramah. Jemaah mereka umumnya adalah jemaah yang setia. Bahkan ke mana pun Guru pergi, mereka ikut menemani, lebih-lebih orang-orang yang berada pada lingkaran terdekat. Kesetiaan para murid ini melahirkan tokoh karismatik yang terorganisir, meskipun tidak formal. Ada orang-orang dekat, yang menjadi perantara, sekaligus menjaga jarak, antara Guru dan para tamunya. Untuk menciptakan rutinitas ini, Guru Zuhdi, ia kadang-kadang juga tampil di televisi, dan ceramahnya disiarkan luas melalui radio. Semua ini merupakan rutinitas (Mujiburrahman dkk., 2012).

Minat masyarakat terletak pada beberapa faktor, yang pertama yaitu pemahaman. Dalam pengajian tasawuf Guru Zuhdi adalah sosok seorang guru pengajian yang mempunyai karisma yang luas, sehingga Guru Zuhdi sangat diterima dalam masyarakat, selain itu dengan penjelasan dan pengajaran yang di uraikan Guru Zuhdi mengutamakan pemahaman dan pengertian peserta pengajian, oleh karena itulah peserta pengajian mudah untuk memahami penjelasan yang di sampaikan dalam pengajian. Yang kedua adalah kegiatan dalam pelaksanaan pengajian yaitu yang diawali dengan salat hajat diteruskan dengan tasmiahan masal serta pembacaan syair yang diiringi dengan alat-alat yang membantu pelaksanaan pembacaan syair, yang ketiga adalah bagi mereka yang suka dengan humor, Guru Zuhdi merupakan seorang sosok yang karismatik di samping itu dalam pengajaranpengajaran yang beliau sampaikan diiringi dengan canda tawa yang bersifat humoris sehingga membuat peserta pengajian senang dan tidak tegang dalam pengajian tersebut (Muhidin, 2015).

Di sisi lain, fanatisme sendiri sering disebut sebagai paham atau merupakan sebuah konsekuensi logis dari kemajemukan sosial atau heterogenitas dunia dan merupakan bentuk solidaritas terhadap orang-orang yang sepaham, dan tidak menyukai kepada orang-orang yang berbeda. Suatu kekeliruan bila masyarakat menganggap fanatisme adalah sesuatu yang benar, seseorang yang terlalu fanatik biasanya dikarenakan dia hanya menafsirkan sesuatu hanya dari satu sudut pandang ilmu saja, bisa di katakan kurangnya pemahaman mengenai ilmu lain dari masyarakat tersebut. Fanatik agama sebenarnya bukan bersumber dari agama 
itu sendiri, tetapi biasanya merupakan kepanjangan dari fanatik etnik atau kelas sosial. Pada hakikatnya, fanatisme merupakan usaha perlawanan kepada kelompok dominan dari kelompok-kelompok minoritas yang pada umumnya tertindas. Minoritas bisa dalam arti jumlah manusia (kuantitas), bisa juga dalam arti minoritas peran (kualitas). Saat ini kehidupan umat beragama dinilai masih belum dapat mencapai titik kedewasaan. Dalam kurun waktu yang singkat banyak terjadi konflik, bahkan menimbulkan peperangan hanya karena satu alasan perbedaan suatu pandangan dalam peribadatan dan kurangnya toleransi untuk menjaga keharmonisan hubungan sosial ('Ayuna \& Nurdin, 2016).

\section{Kesimpulan}

Pada dimensi fanatisme bagian besarnya minat dan kecintaan pada satu jenis kegiatan subjek S dan MI memiliki minat yang kuat, sedangkan subjek MA dan Z memiliki minat yang sangat kuat karena menempel foto Guru Zuhdi di rumah bahkan menyimpan foto serta amalan beliau di catatan khusus, pada sikap pribadi maupun kelompok terhadap kegiatan tersebut subjek S memiliki sikap pribadi yang kuat terhadap pengajian Guru Zuhdi, pada lamanya individu menekuni satu jenis kegiatan tertentu subjek S, MA, dan Z sangat kuat karena sudah lama mengikuti pengajian tersebut sedangkan MI baru 2 tahun ikut pengajian tersebut, pada motivasi yang datang dari keluarga juga mempengaruhi seseorang terhadap bidang kegiatannya subjek S, MA, dan Z mempunyai motivasi yang datang dari keluarga bahkan bersama-sama datang ke pengajian dengan keluarga, sedangkan subjek MI walaupun mendapatkan motivasi dari keluarga tetapi tidak biasa bersama-sama ikut ke pengajian bersama keluarga karena berbeda daerah.

Minat masyarakat terletak pada beberapa faktor, yang pertama yaitu pemahaman. Dalam pengajian tasawuf Guru Zuhdi adalah sosok seorang guru pengajian yang mempunyai karisma yang luas, sehingga Guru Zuhdi sangat diterima dalam masyarakat, selain itu dengan penjelasan dan pengajaran yang di uraikan Guru Zuhdi mengutamakan pemahaman dan pengertian peserta pengajian, oleh karena itulah peserta pengajian mudah untuk memahami penjelasan yang di sampaikan dalam pengajian. Yang kedua adalah kegiatan dalam pelaksanaan pengajian yaitu yang diawali dengan salat hajat diteruskan dengan tasmiahan masal serta pembacaan syair yang diiringi dengan alat-alat yang membantu pelaksanaan pembacaan syair yang ketiga adalah bagi mereka yang suka dengan humor, 
Guru Zuhdi merupakan seorang sosok yang karismatik di samping itu dalam pengajaranpengajaran yang beliau sampaikan diiringi dengan canda tawa yang bersifat humoris sehingga membuat peserta pengajian senang dan tidak tegang dalam pengajian tersebut.

Fanatisme Jamaah Pengajian Agama Terhadap Guru Zuhdi di Mesjid Jami Banjarmasin cenderung lebih kepada fanatisme yang positif, dalam artian tidak berlebihan, para jamaah Masjid Jami di Banjarmasin lebih mengutamakan mendengarkan dan menikmati isi ceramah yang di sampaikan oleh Guru Zuhdi.

\section{Saran}

Bagi peneliti lainnya yang ingin melakukan penelitian yang sama disarankan untuk melakukan survei serta penelitian secara komprehensif agar menemukan aspek lain yang ingin diteliti. Menurut hemat penulis, banyak penelitian serupa yang bisa dilanjutkan, mengingat masih banyak aspek-aspek yang bisa diteliti lebih lanjut. Selain itu disarankan juga meluangkan waktu untuk kajian khazanah lokal, khususnya di daerah Kalimantan Selatan.

\section{Referensi}

'Ayuna, Q., \& Nurdin, S. (2016). Fanatisme Dalam Tinjauan Psikologi Agama. Jurnal Suloh, 1(1), 75-82.

Banjarmasin, K. A. K. (2014). Data Majelis Taklim Kota Banjarmasin Tahun 2014. Kementrian Agama Kota Banjarmasin.

Chaplin, J. (2008). Kamus Lengkap Psikologi.

Faridah, S., \& Mubarak. (2017). Kepercayaan Masyarakat Banjar Terhadap Bulan Safar: Sebuah Tinjauan Psikologi. Al-Banjari, 11(1), 77-92.

Ilhami, H. (2010). Dinamika Islam Tradisional: Potret Praktik Keagamaan Umat Islam Banjarmasin pada bulan Ramadhan 1431 H. Jurnal Darussalam, 2(2).

Lubis, A. S. (2014). Pandangan Ulama dan Intelektual Muslim terhadap Konsep Islam Kultural dan Islam Fundamental dalam Pembangunan Keislaman di Padangsidimpuan. Tazkir, 9(1), 1-27.

MA. (2016, Maret 19). Wawancara Pribadi [Komunikasi pribadi].

Metodologi Penelitian Pendidikan. (2007). PT Rineka Cipta.

Moleong, L. J. (2009). Metode Penelitian Kualitatif. Remaja Rosdakarya.

Muhidin, A. (2015). Pengajian Tasawuf K.H. Zuhdiannor di Jalan Masjid Jami Kelurahan Antasan Kecil Timur Kecamatan Banjarmasin Utara Kota Banjarmasin [Skripsi]. Universitas Islam Negeri Antasari.

Mujiburrahman, Abidin, M. Z., \& Rahmadi. (2012). Ulama Banjar Kharismatik Masa Kini di Kalimantan Selatan: Studi Terhadap Figur Guru Bachiet, Guru Danau, dan Guru Zuhdi. Al-Banjari, 11(2), 107-136.

Prastowo, A. (2011). Metode Penelitian Kualitatif dalam Perspektif Rancangan Penelitian. Ar-Ruzz Media. 
Sugiyono. (2013). Metode Penelitian Pendidikan. CV Alfabeta.

Wibowo, A. (2014). Metodologi Penelitian Praktis Bidang Kesehatan. PT RajaGrafindo Persada.

\begin{tabular}{|l|l|l|l|l|}
\hline Submit & Review & Revisi & Diterima & Publis \\
\hline $23-06-20$ & - & - & $30-03-21$ & $22-04-21$ \\
\hline
\end{tabular}

Novisari, Yulia Hairina, dan Siti Faridah

Program Studi Psikologi Islam

Fakultas Ushuluddin dan Humaniora

Universitas Islam Negeri Antasari Banjarmasin

Email: novisarinovi551@gmail.com 